\title{
Ferns and Lycophytes in Two Areas of Ecotone between Seasonal Semideciduous Forest and Mixed Ombrophilous Forest in Campo Mourão, Paraná, Brazil
}

\author{
Marcelo Galeazzi Caxambú1, Henrique Cesar Lopes Geraldino ${ }^{2 *}$, \\ Ana Claudia Milani Solvalagem ${ }^{3}$ \\ ${ }^{1}$ Curator of the herbarium (HCF), Federal Technologic University of Paraná (UTFPR), Campo Mourão, Brazil \\ ${ }^{2}$ Master in Environmental Sciences, State University of Maringá (UEM), Maringá, Brazil \\ ${ }^{3}$ Environmental Engineer, Federal Technologic University of Paraná (UTFPR), Campo Mourão, Brazil

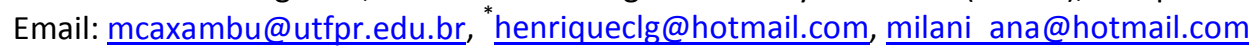

Received 5 January 2015; accepted 23 January 2015; published 27 January 2015

Copyright (C) 2015 by authors and Scientific Research Publishing Inc.

This work is licensed under the Creative Commons Attribution International License (CC BY).

http://creativecommons.org/licenses/by/4.0/

(c) (i) Open Access

\section{Abstract}

The aim of the present study was to present the wealth, ecological characteristics and the floristic similarity of ferns and lycophytes from two forest areas of the municipality of Campo Mourão, PR, Brazil. The vegetation of the municipality is characterized mainly by an ecotone between the Seasonal Semideciduous Forest and Mixed Ombrophilous Forest. We recorded 56 species, distributed in 31 genera and 16 families. The most representative families were Pteridaceae (14) and Polypodiaceae (11) and the wealthier genre was Thelypteris (6). The terricolous species were predominant $(72 \%)$ and the preferential environments were riparian vegetation and forest interior (70\%). The flora of Campo Mourão was more similar to the studies conducted in the state of Rio Grande do Sul, and the cophenetic correlation coefficient $(r=0.9058)$ showed a consistent adjust. In the principal components analysis (PCA) the variance explained by the two principal components was $72.99 \%$. The wealth found in this study corresponds to approximately $11.4 \%$ of the flora of ferns and lycophytes of Paraná. Future contributions are needed to increase the knowledge about the flora of ferns and lycophytes in areas of ecotone, mainly in the region of Campo Mourão, where the studies are scarce.

\section{Keywords}

Diversity, Floristic, Jaccard, Similarity, Lycophytes

\footnotetext{
${ }^{*}$ Corresponding author.
}

How to cite this paper: Caxambú, M. G., Geraldino, H. C. L., \& Solvalagem, A. C. M. (2015). Ferns and Lycophytes in Two Areas of Ecotone between Seasonal Semideciduous Forest and Mixed Ombrophilous Forest in Campo Mourão, Paraná, Brazil. Open Journal of Forestry, 5, 195-209. http://dx.doi.org/10.4236/ojf.2015.52018 


\section{Introduction}

Until the beginning of the 1990s, ferns and lycophytes were treated as a single group of plants and generally classified as belonging to a single paraphyletic division, called Pteridophyte (Prado \& Sylvestre, 2010). Studies based on molecular phylogeny and morphology suggest that in order to properly reflect the evolution of "ferns" as a whole, these plants should be divided into two distinct groups: lycophytes and ferns (Pryer et al. 2001, 2004; Smith et al., 2006, 2008).

As a result of the recognition of paraphyletic groups, several families started to have a lower number of genera and species, while others were united, becoming even larger (e.g. Hymenophyllopsidaceae and Cyatheaceae), and the evolutionary positioning of some groups, before uncertain, now has become more clear (Prado \& Sylvestre, 2010).

According to Moran (2004, 2008), the diversity of these groups follows the gradient of latitudinal diversity, and in both hemispheres the number of species increases approximately thirty times from the poles toward the equator. The highest rates of endemism are found in mountainous areas, due to environmental heterogeneity found in these locations (Moran, 1995). Its distribution is not uniform, and that areas such as the Brazilian Amazon Plain presents a much lower number of species in relation to mountainous areas, such as Ridge of Sea and the Andes, for example (Tryon, 1986; Moran, 1995).

It is estimated that in the world there are approximately 1300 species of ferns and lycophytes (Moran, 2008). In Brazil ferns and lycophytes consist of 1221 species, being the Atlantic Forest the wealthier biome, sheltering 834 species. The south and southeast regions of Brazil concentrate a high number of species, totaling approximately 827 species. In the state of Paraná ferns and lycophytes are represented by 492 species, distributed in 32 families and 103 genera (Prado \& Sylvestre, 2014).

On the study of the flora of ferns and lycophytes in Paraná, stand out: Cislinski (1996), who conducted a survey of the genus Diplazium Sw.; Angely (1963) and Dombrowski (1972) which presented approximately 286 species distributed in 18 families; Cervi et al. (1987), that conducted a survey of ferns in a forest with Araucaria; Dittrich et al. (2005), who developed a survey in Pico do Marumbi State Park in an area of one hectare of Atlantic Forest, where they found 81 species of ferns; Schwartsburd \& Labiak (2007), which studied the ferns of Vila Velha State Park in Ponta Grossa, registering 152 species; Kozera et al. (2009), with a study of a Montane Ombrophilous Dense Forest in Morretes featuring 108 species; and Michelon \& Labiak (2013), that recorded 164 species of ferns and lycophytes in Guartelá State Park at Tibagi.

Ferns and lycophytes were also represented in several studies on vascular epiphytes in the state of Paraná, as Dittrich et al. (1999); Kersten \& Silva (2001, 2002); Borgo et al. (2002); Borgo \& Silva (2003); Gaiotto \& Acra (2005); Cervi \& Borgo (2007); Dettke et al. (2008); Kersten \& Kuniyoshi (2009); Geraldino et al. (2010); Blum et al. (2011); Bianchi et al. (2012) and Bianchi \& Kersten (2014).

The aim of the present study was to present the wealth, ecological characteristics and floristic similarity of ferns and lycophytes in two forest areas of the municipality of Campo Mourão, PR, Brazil.

\section{Material and Method}

\subsection{Study Area}

The municipality of Campo Mourão located in the third Plateau of Paraná, in the Western Center mesoregion of Paraná, situated between the coordinates $23^{\circ} 57^{\prime} 18.26^{\prime \prime}$ and $24^{\circ} 17^{\prime} 53.21^{\prime \prime}$ South latitude and $52^{\circ} 32^{\prime} 41.16^{\prime \prime}$ and $52^{\circ} 11^{\prime} 10.36^{\prime \prime}$ West longitude (Figure 1). It has flat topography, slightly wavy and belongs to the hydrographic basin of Ivaí river, having as the most important tributary Campo river (Ibge, 1997). The soils of the region are classified by the presence of five classes, all evolved from basalt. The most mature soils include Red Latosols and Red Nitosols, while Haplic Cambisols, Litolic and Regolithic Amesols are younger (Bognola et al., 2002; Embrapa, 2006).

The climate of the region, in accordance with the climate classification of Köppen, is classified as Cfa: Mesothermal humid subtropical climate, with hot summers and infrequent frosts, with trend in the concentration of rainfall in summer months, without definite dry season, with the following annual averages: temperature of the hottest months higher than $22^{\circ} \mathrm{C}$ and of coldest months below $18^{\circ} \mathrm{C}$; general temperature of approximately $20^{\circ} \mathrm{C}$; rainfall varies between 1300 and $1600 \mathrm{~mm}$. relative air humidity of 75\%; water index between levels 20 and 60 ; absence of water deficiency. The prevailing winds in the region are those of northeast quadrant, showing probability of frosts in winter months, when blowing from the south and southwest (Maack, 1968). 


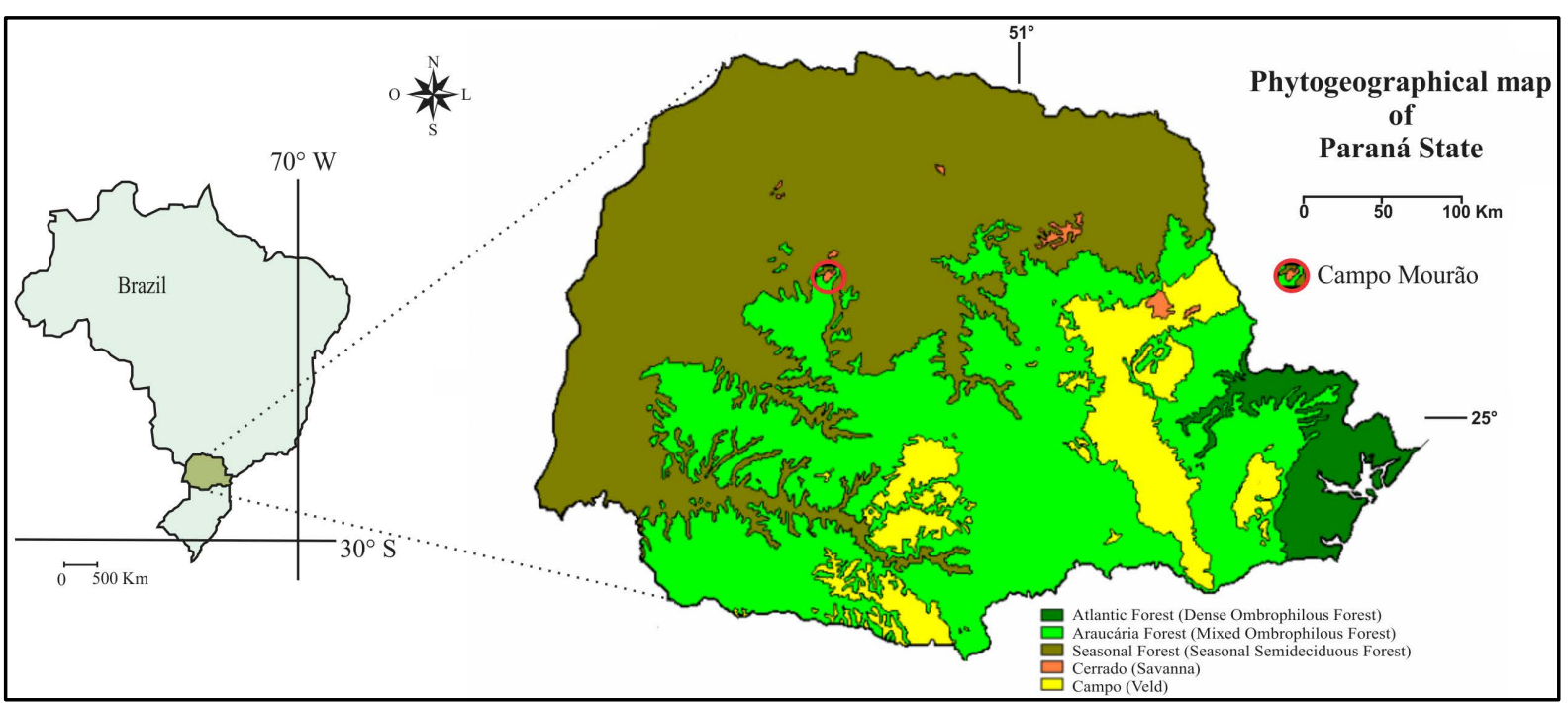

Figure 1. Location map of the study area, municipality of Campo Mourão, Paraná, Brazil. Source: Maack (1950); adaptation: Roderjan et al. (2002).

Regarding vegetation, the municipality of Campo Mourão is characterized by a remarkable phytogeographic diversity, in which two types of forests occur interspersed with herbaceous and shrub formations, forming an ecotone area between the Montane Semideciduous Seasonal Forest and Montane Mixed Ombrophilous Forest. This is so because the altitudinal plateau of the municipality is conflicting with both phytogeographic units, being located approximately 630 meters under the sea level. The Semideciduous Seasonal Forest is situated at altitudes varying from 800 to 200 meters, and the formation of the Mixed Ombrophilous Forest occurs between 400 and 1000 meters of altitude (Roderjan et al., 2002).

The study was conducted in two forest areas, Lago Azul State Park (LA) and Agape home (AH). LA is an important remaining of Montane Semideciduous Seasonal Forest and Montane Mixed Ombrophilous Forest, being the most representative area of this ecotone vegetation in the municipality of Campo Mourão. It has an area of 1749.01 ha and is located on the border with the municipality of Luiziana under the coordinates $24^{\circ} 04^{\prime}$ South latitude and $52^{\circ} 20^{\prime}$ West longitude. The AH area is also formed by ecotone vegetation, has an area relatively smaller than that of the park, with approximately 80 ha, however it presents a well preserved forest area and is located under the coordinates $24^{\circ} 02^{\prime}$ South latitude and $52^{\circ} 22^{\prime}$ West longitude.

\subsection{Methodology}

The collections of ferns and lycophytes were carried out by means of monthly hiking along the preferred environments of occurrence of each group. In the AH area collections occurred during the period from 2005 to 2006 and LA from 2006 to 2008. All ferns and lycophytes were collected and herborized following usual procedures in floristic surveys according to the methodology proposed by Windisch (1990). The collection of epiphytic ferns occurred with high pruning scissors, through natural escalation of phorophyte, and eventually with the use of ladder. The terrestrial individuals were collected with the aid of a mattock or gardening shovel for extraction of the plant with the root.

The classification for families of ferns followed Smith et al. (2006), with modifications presented in Smith et al. (2008), and for the families of lycophytes followed Christenhusz et al. (2011). For the names of the authors we adopted the system proposed by Pichi Sermolli (1996). The identification key was deposited in the collection of the herbarium (HCF) of Federal Technological University of Paraná, campus Campo Mourão. The identifications were made by means of specialized literature, and by comparison with the aid of experts of the Botanical Museum City of Curitiba (herbarium MBM).

For the geographic distribution patterns of taxa, the system proposed by Schwartsburg \& Labiak (2007) was adopted, according to which the species could be classified into: Introduced (species introduced from the Old World in the Americas and nowadays of sub-spontaneous occurrence), Brazilian (endemic species of Brazil), South American (species restricted to the countries of South America), American (species occurring in South 
America, Central America and eventually in North America) and Circum-antarctics (species occurring in America, Africa, Asia and/or Oceania).

The analysis of habits, ways of life and place of occurrence was based on field observations, in the descriptions of exsiccate and works of literature. For the analysis of floristic similarity an array "species $\times$ area" with presence/absence type binary data was drawn up. The wealth of ferns and lycophytes of Campo Mourão was compared to 15 other areas of interest, which made possible to construct a grouping type dendrogram (UPGMA) Unweighted Pair-Group Method Averages, using Jaccard as an index of similarity. The option for the use the Jaccard's index was taken based on its wide use in studies of wealth and composition of vegetation.

For dendrogram construction variations regarding other coefficients of similarity measurement (e.g. Bray-Curtis, Average Euclidean Distance, Absolute Average Distance, Squared Euclidean Distance, Absolute Relative Distance) were performed, in order to check the reliability of the pattern of similarity. The Cophenetic Correlation Coefficient (CCC) was calculated, with the objective of verifying the consistency of the grouping. This coefficient translates the moment-product relation, calculated between the elements of the original matrix and those of the cophenetic matrix, resulting from the simplification provided by the grouping method, after the construction of the dendrogram. Values of CCC above 0.8 indicate good representativeness among distances (Bussad et al., 1990). A Principal Components Analysis (PCA) based on ecological data of ferns and lycophytes of this study was also performed. The Monte Carlo test (99 permutations; $p<0.05$ ) was used in the analysis to inform the likelihood of eigenvalues of the axes to have been or not distributed at random. Analyzes were carried out with the help of the software PAST v.3.02 (Hammer et al., 2001).

For organization of the array of species, all taxa were reviewed in order to identify the "heterotypic synonyms"; such review was based on the database from the Species List of Brazilian Flora (2014) and the Missouri Botanical Garden (2014).

\section{Results}

In the floristic survey were recorded 56 species, distributed in 31 genera and 16 families (Table 1). The most representative families were Pteridaceae (14 spp.) and Polypodiaceae (11 spp.), while Athyriaceae, Davalliaceae, Gleicheniaceae, Lygodiaceae and Osmundaceae were represented by only one species. The LA area was the one that presented the highest wealth with 44 species, being 16 exclusive. The AH obtained a wealth of 39 species, with 11 exclusive. The most abundant genera were Thelypteris (6 spp.), Doryopteris and Pteris (4 spp.) and Anemia, Asplenium, Blechnum, Adiantopsis, Pecluma and Pleopeltis (3 spp.). The total number of species listed in the two areas of study represents approximately $11.4 \%$ of the total estimated for Paraná.

Analyzing the way of life of ferns and lycophytes, it was noted that the majority of species were terricolous (40 spp.); epiphytes were 12 spp., rupicolous 3 spp. and there was only one hemi-epiphyte. In LA distribution was 32 terricolous, 9 epiphytes, 2 rupicolous and 1 hemi-epiphyte; while in the AH area distribution was 25 terricolous, 12 epiphytes and 2 rupicolous. Families that showed exclusively terricolous species were Athyriaceae, Blechnaceae, Cyatheaceae, Davalliaceae, Dennstaedtiaceae, Dryopteridaceae, Gleicheniaceae, Osmundaceae, Selaginellaceae, Tectariaceae and Thelypteridaceae, composing approximately $70 \%$ of the total of surveyed species. The epiphytes were more representative in the Polypodiaceae family with 10 species from a total of 12. Rupicolous ferns were represented by the Anemiaceae family and by one species of the Pteridaceae family. The only hemi-epiphyte found was Lygodium volubile (Lygodiaceae).

These results were very similar to those found by Schmitt et al. (2006) in a survey conducted in the National Forest of Canela in Rio Grande do Sul, where a total of 58 species, 32 genera and 17 families was recorded. In such study the Polypodiaceae family was one of the weathiest with 10 spp. and the genus Thelypteris presented wealth of 6 spp. Gonzatti et al. (2014), in their research performed in a Seasonal Deciduous Forest of Gaúcha Ridge, RS, Brazil, found 70 species distributed in 38 genera and 18 families, in that study the terricolous species presented a value close to the one found in Campo Mourão, with $75 \%$ of the total. The study of Lehn et al. (2009), performed in a Seasonal Deciduous Forest in the Taquari River Valley, RS, Brazil, presented 56 species, 36 genera and 15 families, being observed that $75 \%$ of species occurred in terricolous habit and from 21 to $25 \%$ as epiphytes. The most abundant families were also Polypodiaceae and Pteridaceae. In the study by Schmitt \& Goetz (2010) 62 species distributed in 36 genera and 16 families were observed, terricolous ferns comprised 76\% of the total species, followed by (19\%) epiphytes and (5\%) rupicolous.

Regarding the places of occurrence of ferns and lycophytes, the areas of riparian vegetation and interior of forest were the environments that showed greater wealth, with respectively 20 and 19 spp. The forest edge areas 
Table 1. Ferns and lycophytes occurring in the areas of study: (AH) Agape home, (LA) Lago Azul State Park. Forms of life (FL): Terricolous (Ter), Rupicolous (Rup), Epiphytes (Epf), Hemi-epiphytes (Hpf); Place of occurrence (PO): Edge of forest (Edf), Inside of forest (Inf), Riparian vegetation (Rvg), Outcrop of basalt rock (Abr); Habit (HB): Herbaceous (Hrb), Sub-arborescent (Sub), Scandent herbaceous (Sca); Standard Geographical Distribution (SG): Introduced Old World (Int), Endemic of Brazil (Bra), South America (Sou), American (Ame), Circum-antarctics (Cir).

\begin{tabular}{|c|c|c|c|c|c|c|c|}
\hline \multirow[t]{2}{*}{ Taxa (56) } & \multicolumn{2}{|c|}{ Study areas } & \multicolumn{4}{|c|}{ Ecological observations } & \multirow[t]{2}{*}{ HCF } \\
\hline & AH & LA & FL & PO & HB & SG & \\
\hline \multicolumn{8}{|l|}{ ANEMIACEAE (3) } \\
\hline Anemia phyllitidis (L.) Sw. & $\mathrm{x}$ & $\mathrm{x}$ & Ter & Rvg & Hrb & Ame & 3661 \\
\hline Anemia raddiana Link. & & $\mathrm{x}$ & Rup & Abr & $\mathrm{Hrb}$ & Sou & 4780 \\
\hline Anemia tomentosa (Savigny) Sw. & $\mathrm{x}$ & & Rup & Abr & Hrb & Ame & 3662 \\
\hline \multicolumn{8}{|l|}{ ASPLENIACEAE (4) } \\
\hline Asplenium claussenii Hieron. & $\mathrm{x}$ & $\mathrm{x}$ & Ter & Rvg & Hrb & Ame & 3648 \\
\hline Asplenium gastonis Fée & & $\mathrm{x}$ & Ter & Inf & Hrb & Sou & 5668 \\
\hline Aspleniumscandicinum Kaulf. & $\mathrm{x}$ & & Epf & Inf & Hrb & Sou & 4053 \\
\hline Didymochlaena truncatula (Sw.) J. Sm. & $\mathrm{x}$ & $\mathrm{x}$ & Ter & Inf & Hrb & Cir & 4157 \\
\hline \multicolumn{8}{|l|}{ ATHYRIACEAE (1) } \\
\hline Diplazium cristatum (Desr.) Alson & & $\mathrm{x}$ & Ter & Rvg & Hrb & Ame & 4748 \\
\hline \multicolumn{8}{|l|}{ BLECHNACEAE (3) } \\
\hline Blechnum brasiliense Desv. & $\mathrm{x}$ & $\mathrm{x}$ & Ter & Rvg & Hrb & Sou & 3667 \\
\hline Blechnum gracile Kaulf. & $\mathrm{x}$ & & Ter & Rvg & Hrb & Sou & 3684 \\
\hline Blechnum polypodioides Raddi & $\mathrm{x}$ & $\mathrm{x}$ & Ter & Rvg & Hrb & Sou & 3670 \\
\hline \multicolumn{8}{|l|}{ CYATEACEAE (2) } \\
\hline Cyathea atrovirens (Langsd. \& Fisch.) Domin & $\mathrm{x}$ & $\mathrm{x}$ & Ter & Rvg & Sub & Sou & 4160 \\
\hline Cyathea delgadii Sternb. & $\mathrm{x}$ & $\mathrm{x}$ & Ter & Rvg & Sub & Sou & 4677 \\
\hline \multicolumn{8}{|l|}{ DAVALLIACEAE (1) } \\
\hline Nephrolepis exaltata (L.) Schott. & & $\mathrm{x}$ & Ter & Abr & Hrb & Cir & 4772 \\
\hline \multicolumn{8}{|l|}{ DENNSTAEDTIACEAE (2) } \\
\hline Dennstaedtia dissecta (Sw.) T. Moore & $\mathrm{x}$ & & Ter & Inf & Hrb & Ame & 4163 \\
\hline Pteridium arachnoideum (Kaulf.) Maxon & $\mathrm{x}$ & $\mathrm{x}$ & Ter & Edf & Hrb & Ame & 6642 \\
\hline \multicolumn{8}{|l|}{ DRYOPTERIDACEAE (3) } \\
\hline Ctenitis submarginalis (Langsd. \& Fisch.) Ching. & $\mathrm{x}$ & $\mathrm{x}$ & Ter & Inf & Hrb & Ame & 4784 \\
\hline Lastreopsis effusa (Sw.) Tindale & $\mathrm{x}$ & $\mathrm{x}$ & Ter & Inf & Hrb & Ame & 4159 \\
\hline Megalastrum connexum (Kaulf.) A.R. Sm. \& R.C. Moran & $\mathrm{x}$ & & Ter & Rvg & Hrb & Sou & 4156 \\
\hline \multicolumn{8}{|l|}{ GLEICHENIACEAE (1) } \\
\hline Sticherus penniger (Mart.) Copel & $\mathrm{x}$ & & Ter & Rvg & Hrb & Ame & 4162 \\
\hline \multicolumn{8}{|l|}{ LYGODIACEAE (1) } \\
\hline Lygodium volubile Sw. & & $\mathrm{x}$ & Hpf & Inf & Sca & Cir & 5661 \\
\hline \multicolumn{8}{|l|}{ OSMUNDACEAE (1) } \\
\hline Osmunda regalis $\mathrm{L}$. & & $\mathrm{x}$ & Ter & Rvg & Hrb & Cir & 4935 \\
\hline \multicolumn{8}{|l|}{ POLYPODIACEAE (11) } \\
\hline Campyloneurum nitidum (Kaulf.) C. Presl & $\mathrm{x}$ & $\mathrm{x}$ & Epf & Inf & Hrb & Sou & 3651 \\
\hline
\end{tabular}




\section{Continued}

Microgrammasquamulosa (Kaulf.) de la Sota

Niphidium crassifolium (L.) Lellinger

Pecluma paradiseae (Langsd. \& Fisch.) M.G. Price

Pecluma pectinatiformis (Lindm.) M.G. Price

Pecluma sicca (Lindm.) M.G. Price

Pecluma truncorum (Lindm.) M.G. Price

Pleopeltis hirsutissima (Raddi) de la Sota

Pleopeltis pleopeltifolia (Raddi) Alston

Pleopeltis minima (Bory) J. Prado \& R.Y. Hirai

Serpocaulon latipes (Langsd. \& Fisch.) A.R. Sm

PTERIDACEAE (14)

Adiantopsis chlorophylla (Sw.) Fée

Adiantopsis radiata (L.) Fée

Adiantum raddianum C. Presl.

Adiantum tetraphillum Humb. \& Bonpl. ex Willd

Doryopteris concolor (Langsd. \& Fisch.) J. Sm

Doryopteris nobilis (T. Moore) C. Chr.

Doryopteris pedata var. multipartita (Fée) R.M. Tryon

Doryopteris pentagona Pic. Serm

Pityrogramma trifoliata (L.) R.M. Tryon

Pteris brasiliensis Raddi

Pteris deflexa Link

Pteris denticulata Sw.

Pteris lechleri Mett.

Vittaria lineata (L.) J. Smith

SELAGINELLACEAE (1)

Selaginellasulcata (Desv. ex Poir.) Spring ex. Mart.

TECTARIACEAE (2)

Tectaria incisa Cav.

Tectaria trifoliata (L.) Cav.

THELYPTERIDACEAE (6)

Thelypteris dentata (Forssk.) E.P. St. John

Thelypteris interrupta (Willd.) K. Iwats

Thelypteris opposita (Vahl) Ching

Thelypteris rivularioides (Fée) Abbiatti

Thelypteris salzmannii (Fée) C.V. Morton

Thelypteris serrata (Cav.) Alston

\begin{tabular}{|c|c|c|c|c|c|c|}
\hline $\mathrm{x}$ & $\mathrm{x}$ & Epf & Edf & Hrb & Ame & 2787 \\
\hline $\mathrm{x}$ & $\mathrm{x}$ & Epf & Inf & Hrb & Ame & 3678 \\
\hline $\mathrm{x}$ & & Ter & Inf & Hrb & Bra & 3686 \\
\hline $\mathrm{x}$ & & Epf & Edf & Hrb & Sou & 3605 \\
\hline \multirow[t]{2}{*}{$\mathrm{x}$} & $\mathrm{x}$ & Epf & Edf & Hrb & Sou & 4122 \\
\hline & $\mathrm{x}$ & Epf & Inf & Hrb & Sou & 5906 \\
\hline $\mathrm{x}$ & $\mathrm{x}$ & Epf & Edf & Hrb & Sou & 4997 \\
\hline $\mathrm{x}$ & $\mathrm{x}$ & Epf & Edf & Hrb & Sou & 2810 \\
\hline $\mathrm{x}$ & $\mathrm{x}$ & Epf & Edf & Hrb & Sou & 3273 \\
\hline $\mathrm{x}$ & & Epf & Rvg & Hrb & Ame & 4153 \\
\hline $\mathrm{x}$ & $\mathrm{x}$ & Rup & Abr & Hrb & Sou & 3664 \\
\hline \multirow[t]{4}{*}{$\mathrm{x}$} & $\mathrm{x}$ & Ter & Edf & Hrb & Ame & 3266 \\
\hline & $\mathrm{x}$ & Ter & Edf & Hrb & Sou & 7146 \\
\hline & $\mathrm{x}$ & Ter & Rvg & Hrb & Ame & 6632 \\
\hline & $\mathrm{x}$ & Ter & Inf & Hrb & Sou & 4779 \\
\hline $\mathrm{x}$ & $\mathrm{x}$ & Ter & Inf & Hrb & Sou & 3685 \\
\hline \multirow[t]{4}{*}{$\mathrm{x}$} & $\mathrm{x}$ & Ter & Inf & Hrb & Sou & 3665 \\
\hline & $\mathrm{x}$ & Ter & Abr & Hrb & Sou & 4742 \\
\hline & $\mathrm{x}$ & Ter & Inf & Hrb & Ame & 5005 \\
\hline & $\mathrm{x}$ & Ter & Inf & Hrb & Sou & 5043 \\
\hline $\mathrm{x}$ & $\mathrm{x}$ & Ter & Rvg & Hrb & Ame & 4678 \\
\hline $\mathrm{x}$ & & Ter & Rvg & Hrb & Ame & 4054 \\
\hline $\mathrm{x}$ & $\mathrm{x}$ & Ter & Rvg & Hrb & Ame & 3683 \\
\hline $\mathrm{x}$ & $\mathrm{x}$ & Epf & Inf & Hrb & Ame & 4055 \\
\hline $\mathrm{x}$ & $\mathrm{x}$ & Ter & Edf & Hrb & Sou & 4170 \\
\hline \multirow[t]{2}{*}{$\mathrm{x}$} & $\mathrm{x}$ & Ter & Inf & Hrb & Ame & 4158 \\
\hline & $\mathrm{x}$ & Ter & Inf & Hrb & Sou & 5659 \\
\hline \multirow[t]{2}{*}{$\mathrm{x}$} & $\mathrm{x}$ & Ter & Edf & Hrb & Int & 4154 \\
\hline & $\mathrm{x}$ & Ter & Edf & Hrb & Cir & 5671 \\
\hline \multirow[t]{3}{*}{$\mathrm{x}$} & & Ter & Rvg & Hrb & Ame & 4152 \\
\hline & $\mathrm{x}$ & Ter & Rvg & Hrb & Sou & 6607 \\
\hline & $\mathrm{x}$ & Ter & Rvg & Hrb & Sou & 4883 \\
\hline $\mathrm{x}$ & & Ter & Rvg & Hrb & Ame & 4051 \\
\hline
\end{tabular}


registered 12 spp. and the outcrops of basalt rock, 5 spp. Athyriaceae, Blechnaceae, Cyatheaceae, Gleicheniaceae and Osmundaceae families were exclusive of areas of riparian vegetation, Lygodiaceae and Tectariaceae occurred exclusively in the interior of forest. The species that occurred in outcrop of basalt rock were represented by Anemiaceae (2 spp.), Pteridaceae (2 spp.) and Davalliaceae (1 spp.) families. The only family exclusive of forest edge was Selaginellaceae with Selaginella sulcata.

Most ferns and lycophytes found in this study were classified as South American and American, according to the pattern of geographical distribution, showing respectively 27 and 22 spp. Only five were classified Circumantarctic. Thelypteris dentata was the only fern classified as Introduced, and only Pecluma paradiseae as endemic to Brazil, having occurred only in the AH area.

For the analysis of the floristic similarity were selected some studies of interest on ferns and lycophytes carried out in the South and Southeast regions of the country, where there is occurrence of Seasonal and Ombrophilous Forests, in addition to Grasslands and Cerrado (Table 2) areas. For this analysis there were no significant differences in the pattern of similarity when tested other indexes.

The grouping analysis (Figure 2) revealed the formation of three main groups in the dendrogram. The first group, located to the left of the dendrogram, is composed by areas 03, 01 and 02 , which were the wealthiest among the studies of Paraná. Areas 01 and 02 have geographical proximity (approximately $80 \mathrm{Km}$ ) and are located in the region of "campos gerais", being one in Tibagi (02) and the other in Ponta Grossa (01). They have similarity both in the type of vegetation (Grasslands and MOF) and in number of species found (164 and 152, respectively). The area (03) located in the municipality of Morretes is in coastal area and presents DOF characteristic vegetation, but resembles the other ones by the presence of MOF.

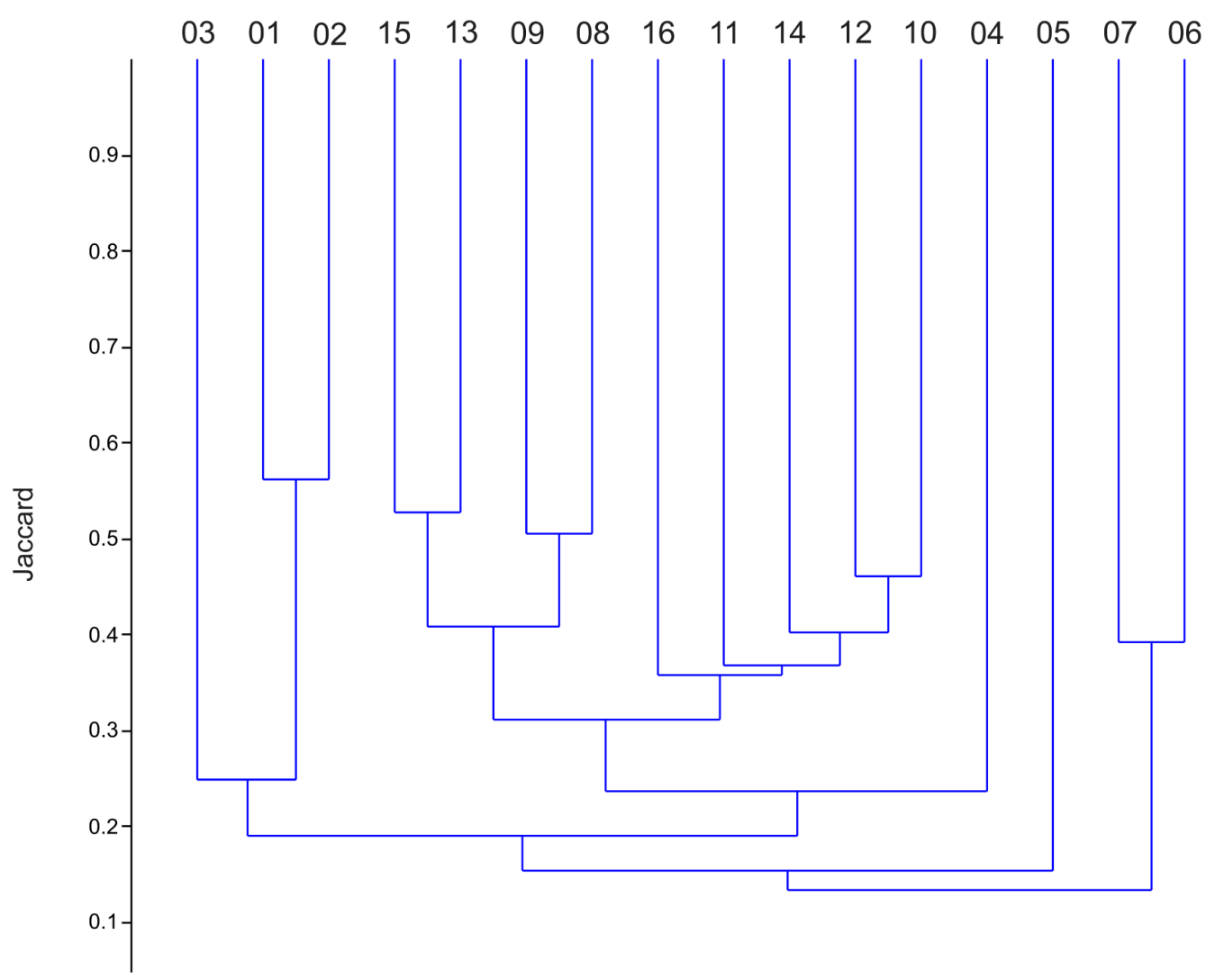

Figure 2. Dendrogram of floristic similarity obtained by the method of non-weighted average (UPGMA) based on Jaccard's index, among the 16 areas of interest. 01: Vila Velha State Park, PR; 02: Guartelá State Park, PR; 03: Pico do Marumbi State Park, PR; 04: Campo Mourão, PR; 05: Mun. Botanical Garden of Bauru, SP; 06: Vassununga State Park, SP; 07: State Reserve of Águas da Prata, SP; 08: Urban Park, RS; 09: National Forest of Canela, RS; 10: Harmonia Hill, RS; 11: Taquari River Valley, RS; 12: Gaúcha Ridge, RS; 13: Cadeia River, RS; 14: Sinos River Basin, RS; 15: Mun. Natural Park of Ronda, RS; 16: Mun. Park Henrique L. Roessler, RS. 
Table 2. Relationship of the areas used in the study of similarity. GSL: Grasslands; CER: Cerrado; SDF: Seasonal Deciduous Forest; SSF: Seasonal Semideciduous Forest; DOF: Dense Ombrophilous Forest; MOF: Mixed Ombrophilous Forest.

\begin{tabular}{lcccc}
\hline $\mathbf{N}^{\circ}$ & Study areas & Vegetation type & $\mathbf{N}^{\circ}$ Spp. & References \\
\hline 01 & Vila Velha State Park, PR & GSL/MOF & 152 & Schwartsburd \& Labiak (2007) \\
02 & Guartelá State Park, PR & GSL/MOF & 164 & Michelon \& Labiak (2013) \\
03 & Pico do Marumbi State Park, PR & DOF/MOF & 81 & Dittrich et al. (2005) \\
04 & Campo Mourão, PR & SSF/MOF & 56 & This study \\
05 & Mun. Botanical Garden of Bauru, SP & SSF/CER & 49 & Nóbrega \& Prado (2008) \\
06 & Vassununga State Park, SP & SSF & 34 & Colli et al. (2004) \\
07 & State Reserve of Águas da Prata, SP & SSF & 39 & Colli et al. (2007) \\
08 & Urban Park, RS & GSL/MOF & 81 & Goetz et al. (2012) \\
09 & National Forest of Canela, RS & GSL/MOF & 58 & Schmitt et al. (2006) \\
10 & Harmonia Hill, RS & SSF/MOF & 71 & Steffens \& Windisch (2007) \\
11 & Taquari River Valley, RS & SDF & 56 & Lehn et al. (2009) \\
12 & Gaúcha Ridge, RS & SDF & 74 & Gonzatti et al. (2014) \\
13 & Cadeia River, RS & SSF & 40 & Mallmann \& Schmit (2014) \\
14 & Sinos River Basin, RS & DOF/MOF & 62 & Becker et al. (2013) \\
15 & Mun. Natural Park of Ronda, RS & MOF & 42 & Blume et al. (2010) \\
16 & Mun. Park Henrique L. Roessler, RS & SSF & 43 & Schmitt \& Goetz (2010) \\
\hline
\end{tabular}

The second group located in the center of the dendrogram, covers a larger number of areas $(15,13,09,08,16$, $11,14,12,10)$ and includes all the surveys conducted in the state of Rio Grande do Sul. Among the vegetation present in these areas are SSF, MOF, SDF, DOF and FDL. In this group occurs also the formation of two subgroups, one covering the areas 15, 13, 09 and 08, being the most similar ones and with the predominance of MOF, and the other with the areas 16, 11, 14, 12 and 10 having predominance of SDF/SSF. All areas of RS present geographical proximity, being concentrated in a radius of $130 \mathrm{Km}$, in the metropolitan mesoregion of Porto Alegre.

A third group can be observed on the right side of the dendrogram, composed of only two areas (07 and 06), both located in the state of São Paulo and with the occurrence of SSF. The number of species recorded in these areas was also very similar (39 and 34 spp., respectively). The area of Campo Mourão, PR (04), together with Bauru, SP (05), showed low rates of similarities and had no well-defined groups.

Regarding the similarity index, it can be observed (Table 3) that there were variations between 0.0424 and 0.5619. The highest floristic similarities occurred between areas 01 and 02 (56\%), 15 and 13 (53\%) and 09 and 08 (51\%). According to Magurran (2004) a similarity (>0.5) is considered to be high, and the closer the value to 1 , the higher the similarity.

Analyzing Figure 2, it is observed that the area of Campo Mourão had greater similarity with the group of Rio Grande do Sul, and Jaccard's index presented variations from 0.1351 to 0.2766 . The authors Müller-Dombois \& Ellenberg (1974) suggest that the Jaccard's index should present at least 25\% of common species between two communities, so that occurs the floristic similarity. In this way, it can be said that there was similarity of Campo Mourão only with areas 07 (26\%), 16 (25\%), 11 (27\%), 14 (25\%), 12 (27\%) and 10 (28\%). Area 5 obtained all similarity index lower than 20\%. The Cophenetic Correlation Coefficient $(r=0.9058)$ presented high adjustment between the graphical representation of the distances in the dendrogram and its original matrix.

Low similarity found in this study was already expected, and is justified by the low number of studies cited for Paraná, and also by the different vegetation types found in most areas. Studies on ferns and lycophytes in areas of ecotone involving the biomes SSF/MOF are still scarce in Paraná, mainly in the region of Campo Mourão, and this relatively makes the performance of comparative studies difficult. 
Table 3. Similarity matrix (Jaccard) between the 16 areas of study.

\begin{tabular}{|c|c|c|c|c|c|c|c|c|c|c|c|c|c|c|c|c|}
\hline & 04 & 05 & 07 & 06 & 03 & 15 & 16 & 13 & 11 & 09 & 14 & 12 & 10 & 08 & 01 & 02 \\
\hline 04 & 1.0000 & & & & & & & & & & & & & & & \\
\hline 05 & 0.2299 & 1.0000 & & & & & & & & & & & & & & \\
\hline 07 & 0.2568 & 0.1688 & 1.0000 & & & & & & & & & & & & & \\
\hline 06 & 0.1733 & 0.0759 & 0.3922 & 1.0000 & & & & & & & & & & & & \\
\hline 03 & 0.1351 & 0.0424 & 0.1010 & 0.1183 & 1.0000 & & & & & & & & & & & \\
\hline 15 & 0.1687 & 0.0805 & 0.0811 & 0.0563 & 0.1771 & 1.0000 & & & & & & & & & & \\
\hline 16 & 0.2468 & 0.1923 & 0.1618 & 0.1045 & 0.1200 & 0.2969 & 1.0000 & & & & & & & & & \\
\hline 13 & 0.2208 & 0.1235 & 0.1159 & 0.0909 & 0.1000 & 0.5283 & 0.3333 & 1.0000 & & & & & & & & \\
\hline 11 & 0.2674 & 0.1778 & 0.1795 & 0.1299 & 0.1364 & 0.2308 & 0.3380 & 0.2400 & 1.0000 & & & & & & & \\
\hline 09 & 0.2043 & 0.1474 & 0.1177 & 0.0843 & 0.1228 & 0.3562 & 0.4412 & 0.3714 & 0.3374 & 1.0000 & & & & & & \\
\hline 14 & 0.2528 & 0.1684 & 0.1548 & 0.1220 & 0.1404 & 0.2785 & 0.3514 & 0.2895 & 0.3452 & 0.3488 & 1.0000 & & & & & \\
\hline 12 & 0.2680 & 0.1651 & 0.2184 & 0.1744 & 0.1120 & 0.2360 & 0.3457 & 0.3049 & 0.3118 & 0.3441 & 0.4111 & 1.0000 & & & & \\
\hline 10 & 0.2766 & 0.1471 & 0.2410 & 0.1529 & 0.1525 & 0.2442 & 0.3947 & 0.2683 & 0.4512 & 0.3407 & 0.3933 & 0.4615 & 1.0000 & & & \\
\hline 08 & 0.2273 & 0.1892 & 0.1569 & 0.0971 & 0.1890 & 0.5062 & 0.3297 & 0.4000 & 0.3400 & 0.5055 & 0.3628 & 0.3455 & 0.3303 & 1.0000 & & \\
\hline 01 & 0.2317 & 0.1706 & 0.1145 & 0.1043 & 0.2316 & 0.1813 & 0.1899 & 0.1698 & 0.2256 & 0.2515 & 0.2118 & 0.2356 & 0.2254 & 0.2971 & 1.0000 & \\
\hline 02 & 0.2197 & 0.1620 & 0.0960 & 0.1053 & 0.2682 & 0.1716 & 0.1868 & 0.1607 & 0.2209 & 0.2102 & 0.2286 & 0.2240 & 0.2077 & 0.2967 & 0.5619 & 1.0000 \\
\hline
\end{tabular}

The study of Dittrich et al. (2005), carried out in Pico do Marumbi State Park, PR, Brazil, occurred in a location with presence of DOF/MOF revealing a wealth of 81 species in a small area of 1 ha. This high wealth in such a small area can be related to the fact that DOF is predominant on the site, directly influencing the results of the study. According to Prado (1998), the main center of endemism in Brazil for this group of plants is located within the limits of the Atlantic Woods, especially in the South and Southeast regions of the country. It is estimated that there are approximately 253 species of ferns and lycophytes in this biome only in the state of Paraná (Prado \& Sylvestre, 2014).

Blum et al. (2011) investigated the wealth of vascular epiphytes in Prata Ridge in the municipality of Morretes, PR, Brazil, in an area of 6.3 ha with occurrence of DOF. In this study the ferns and epiphytic lycophytes were responsible for 74 species, 30 genera and 10 families. By analyzing these data it can be said that areas of DOF are so wealthy that the ferns epiphytes found in Morretes by themselves have greater wealth than those of many studies on ferns and lycophytes, in a general way, in other forest formations of Paraná.

Besides the vegetable typologies, other factors that may also influence the wealth of ferns and lycophytes are the different phyto-physiognomic configurations and geological characteristics of certain environments (e.g. grassland vegetation, cerrado, rupestrian and arenitic areas), thatare often associated with forest formations. This can be observed, for example, in the study of Michelon \& Labiak (2013) who recorded 164 species, of which approximately 32\% were characteristic of grassland vegetation. In the study of Schwrtsburg \& Labiak (2007), from 152 species recorded, 25 were exclusive of general grasslands, 12 of humid grasslands, 8 of dry grasslands and 19 of arenitic formations, totaling $42 \%$ of total wealth. In a study conducted in an urban park, Goetz et al. (2012) found 81 species of ferns and lycophytes in area of MOF with presence of altitude grasslands. Schmitt et al. (2006), in a study in the National Forest of Canela recorded 58 species in area of MOF with presence of wetlands and grasslands.

Another comparative analysis performed in this study refers to the floristic similarity of ferns and lycophytes considering only one of the forest areas. In Figure 3 we can note two dendrograms; one presents an analysis of similarity of Campo Mourão with other areas of Seasonal Forest (A); the other compares the wealth of Campo Mourão with areas of occurrence of Mixed Ombrophilous Forest (B). In the dendrogram A one notes that Campo Mourão (04) showed similarity with the areas 16, 11, 12, 10 and 13 with the respective Jaccard's index of 


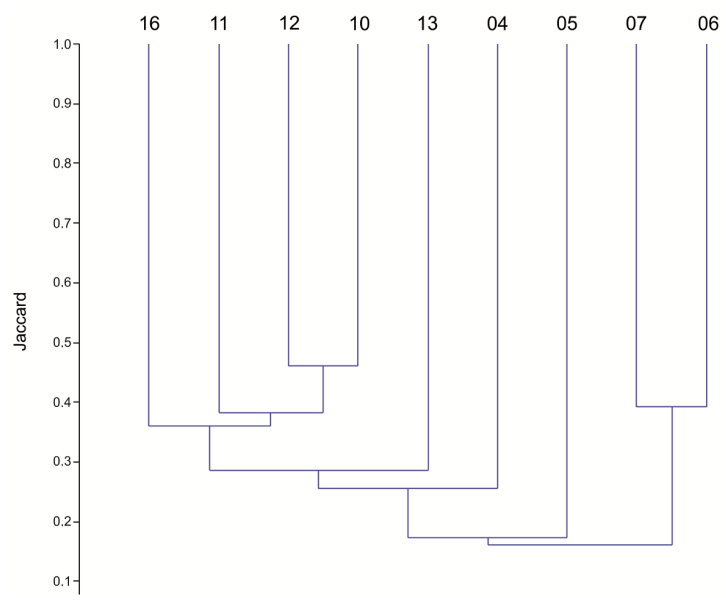

(a)

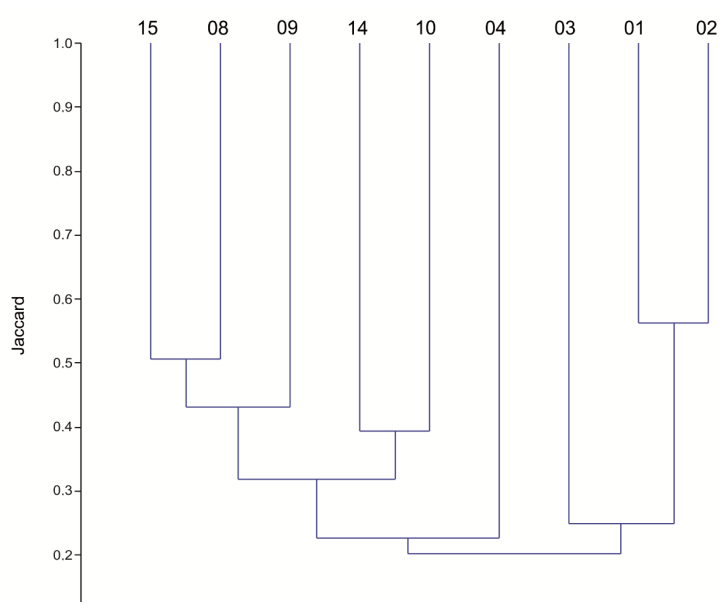

(b)

Figure 3. Dendrogram of floristic similarity obtained by the method of non-weighted average (UPGMA) based on Jaccard's index. A: Areas with incidence of Seasonal Forest; B: Areas with incidence of Ombrophilous Forest. 01: Vila Velha State Park, PR; 02: Guartelá State Park, PR; 03: Pico do Marumbi State Park, PR; 04: Campo Mourão, PR; 05: Mun. Botanical Garden of Bauru, SP; 06: Vassununga State Park, SP; 07: State Reserve of Águas da Prata, SP; 08: Urban Park, RS; 09: National Forest of Canela, RS; 10: Harmonia Hill, RS; 11: Taquari River Valley, RS; 12: Gaúcha Ridge, RS; 13: Cadeia River, RS; 14: Sinos River Basin, RS; 15: Mun. Natural Park of Ronda, RS; 16: Mun. Park Henrique L. Roessler, RS.

$0.25 ; 0.27 ; 0.27 ; 0.28$ and 0.27 . Area 05 obtained index of similarity lower than $25 \%$ and the areas 07 and 06 were in a separate group.

Cophenetic Correlation Coefficient in this group was $(r=0.9028)$ proving the consistency of the adjustment. In the dendrogram B one can observe the formation of two groups, one to left formed by areas 15, 08, 09, 14 and 10 and the other to the right, composed by areas 03, 01 and 02. Campo Mourão (04) showed similarity only with areas 14 and 10 with the respective similarity index 0.25 and 0.28 . In this group Cophenetic Correlation Coefficient was 0.9017 and also proved the consistency of the adjustment.

The fact that Campo Mourão have shown greater similarity in the dendrogram A can be related to the majority of the areas of Deciduous Forests not showing another type of associated vegetation, i.e., from the eight analyzed areas only two have other type of associated vegetation (SSF/SVN and SSF/MOF). In dendrogram B there were eight areas of Ombrophilous Forest with only one exclusive and the other seven showing another type of associated vegetation (4 FLD/MOF, 2 DOF/MOF and $1 \mathrm{SSF} / \mathrm{MOF}$ ). This factor probably affected the similarity in dendrogram B, since Campo Mourão did not register ferns and lycophytes in areas of Grasslands and Cerrado.

In the Principal Components Analysis (PCA), are presented the ecological characteristics of environmental variables in relation to the areas of ecotone (Figure 4). PC1 axis explained $43.68 \%$ of the total variance of data, being that the characters with greater positive value and significant were Ame with 0.46 , Rvg with 0.42 and Ter with 0.38; most significant negative characters were Sou with -0.47 , Edf with -0.38 and Epf with -0.32 . PC2 axis explained $29.31 \%$ of the total variance and showed the following positive and most significant characters, being South with 0.53 , Rvg with 0.40 and Ter with 0.34 , and the negative ones were Ame with -0.50 and Epf with 0.31 . The total variance explained by the two principal components was $72.99 \%$.

The test of permutation of Monte Carlo presented $(p=0.005)$, indicating that the relationship "species-variables" in the two axes were significant. According to Johnson \& Wichern (2002), a large part of the total variability (over 70\%) can be explained by one, two or three main components, then such component scan replace the original variables, without great loss of information.

The PCA has shown that the terricolous species (Ter) showed association with environments of riparian vegetation (Rvg), as well as epiphytic species (Epf) were associated with environments of the edge of forest (Edf). The ferns terricolous were the most abundant (76\%), and its association with areas of riparian vegetation is related to the fact that these areas have a habitat conducive to the development of ferns and lycophytes. The ferns in their majority, mainly occur in the understory of the forest, they have a high photosynthetic capacity under lowlight intensity and its preference for riparian forests are with the trend that these plants have to established in shaded locations and humid places, where are offered the microclimates suitable for reproduction (Páusas \& Sáez, 2000; Page, 2002). 


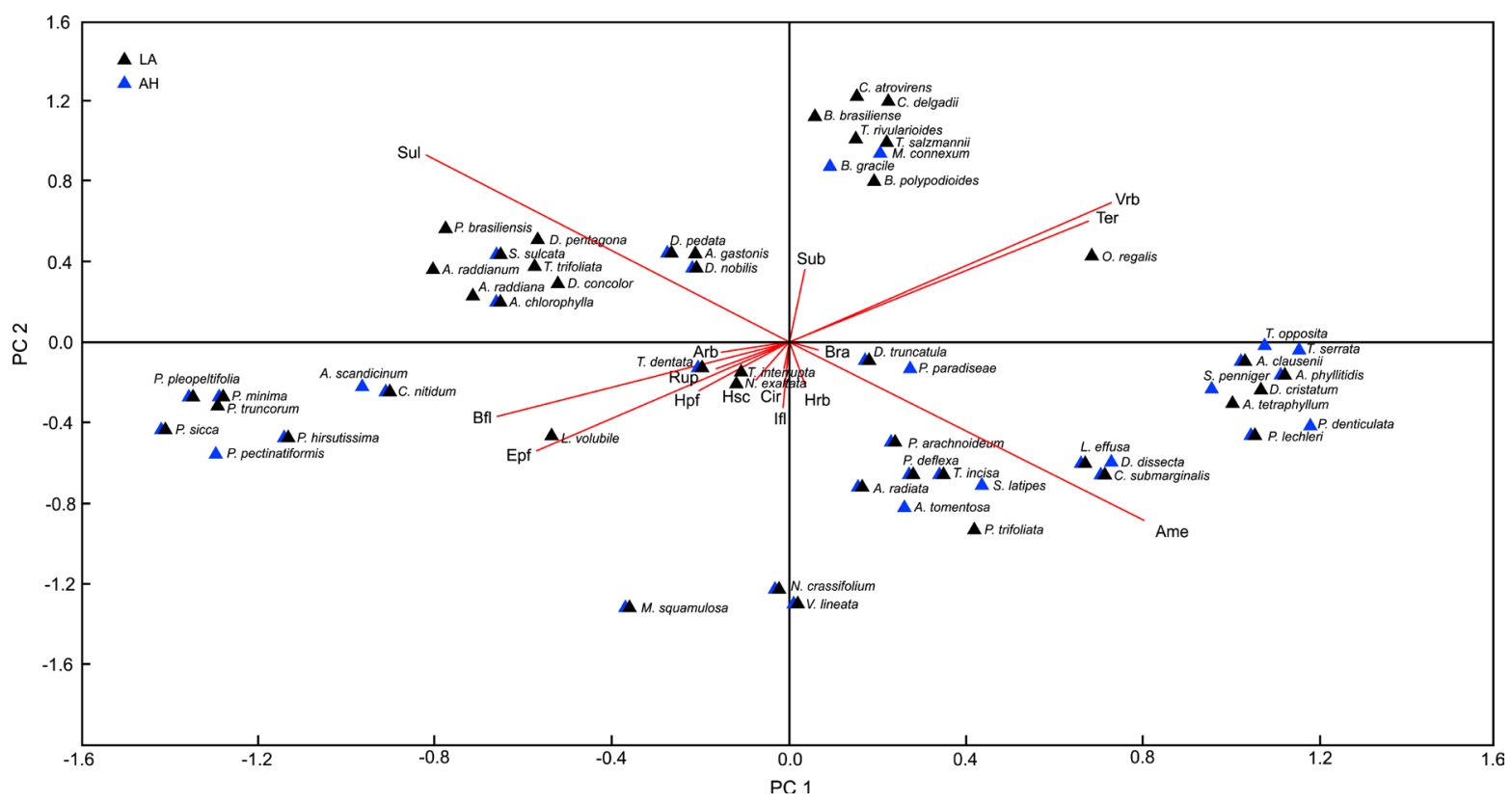

Figure 4. Principal component analysis (PCA) of ferns and lycophytes of Campo Mourão. Terricolous (Ter), Rupicolous (Rup), Epiphytes (Epf), Hemi-epiphytes (Hpf), Edge of forest (Edf), Interior of forest (Inf), Riparian vegetation (Rvg), Outcrop of basalt rock (Abr), Herbaceous (Hrb), Sub-arborescent (Sub), Scandent herbaceous (Sca), Introduced old world (Int), Endemic of Brazil (Bra), South American (Sou), American (Ame), Circum-antarctic (Cir).

Regarding areas of edge, where observed associations with epiphytic species, it can be said that they are environments where climatic conditions tend to a drastic change in relation to the forest interior. In edges the light and temperature are more intense, resulting in soil warmer and, consequently, less wet. The humidity is lower than in the rest of the forest and with this the leaves lose more water through transpiration. All of these factors create an environment that is hostile to ferns and inhibits the development of some species less tolerant.

The epiphytic ferns develop its life cycle above the ground, fixed in trees (phorophytes), which in turn, support and a micro-habitat ideal for its development. Therefore, in open areas or forest edges, is more common epiphytic ferns are more abundant than the terricolous.

The occupation of these plants seems to be related to abiotic factors such as the search for water, nutrients and luminosity. The uptake of water and nutrients occurs directly through atmosphere, whether by particulate matter or by rain water, direct or leachate of crowns. Canopies, water evaporates, falls as large drops or drains the trunks, suffering chemical changes during the course. In genera $10 \%$ to $30 \%$ of incident precipitation is retained and evaporates directly from the canopy. The water that reaches the soil, up to $85 \%$ may come from drops and up to 30\% can seep from the trunk (Benzing, 1995; Parker, 1995; Zotz \& Hietz, 2001). Humidity increases the canopy to the ground, while luminosity follows an opposite trend. The thermal amplitude daily varies as it moves away from the ground, being the poster the part with greater fluctuations in temperature. The temperature can vary by several degrees between the canopy and ground floor, directly influencing the relative humidity of the air. Close to the floor, this remains practically constant and close to $100 \%$, while that in pantry can be between 50 and 60\% (Benzing, 1995).

The majority of the species surveyed were frequent in both study areas, with a wide distribution in relation to ecological variables. The ferns and lycophytes exclusive of LA area showed greater uniformity in relation to ecological variables. And the exclusive species of $\mathrm{AH}$ area are distributed in most the right side of the graph, and is strongly associated with the variables Rvg, Ter and Ame. This distribution can be related to the type of environment that is to be found in AH, since, for this property the river "Campo" crosses the forest area from north to south, thus exerting great influence under the richness of ferns and lycophytes, which showed its largest distribution over to the course of the river. The only species of the AH area located on the left side of the graph were $A$. scandicinum and $P$. pectinatiformis.

In general, the species more frequent considering all areas analyzed were: Microgramma squamulosa, only to submit distribution in the 16 areas analyzed, Anemia phyllitidis, was the second most frequent with distribution 
in 15 areas, Ctenitis submarginalis and Macrothelypteris torresiana presented frequency in 14 areas, Asplenium claussenii, Pleopeltis hirsutissima and Rumohra adiantiformis, were observed in 13 areas, and Adiantum raddianum, Blechnum binervatum, Pteridium arachnoideum e Vittaria lineata, observed in 12 areas of study.

\section{Conclusions}

The families that showed greater wealth were Pteridaceae (14 spp.), Polypodiaceae (11 spp.) and the lypteridaceae (6 spp.), representing 55\% of the total, and the latter, the family that had the most abundant genus, Thelypteris (6 spp.). The form of terricolous life was observed in $72 \%$ of the species and showed association with the environment of riparian vegetation. The epiphytic habit (22\%) was associated with areas of forest edge.

The low similarity found in this study is mainly related to the fact that most comparative studies have been carried out in other states, and also to the great variation of the biomes present in these areas. The specific richness recorded for Campo Mourão represents approximately 11.4\% of the total of ferns and lycophytes described for Paraná.

The composition of species obtained in this inventory is an important contribution to our knowledge of the flora of ferns and lycophytes in areas of ecotone with occurrence of SSF/MOF in Paraná, and mainly in the region of Campo Mourão. It is also essential for the completion of further studies on the interactions plant/environment which occur in this ecosystem.

\section{Acknowledgements}

We thank the staff of collection of the Herbarium of Federal Technological University of Paraná at Campo Mourão campus (HCF) by aidinfield and for the support of the entire work; teacher Celso Aparecido Gandolfo (in memoriam) by valuable research support; experts in the Botanical Museum City of Curitiba (herbarium MBM) by the aid of determinations.

\section{References}

Angely, J. (1963). Flora Pteridophyta of Paraná. Paranaense Botanical Institute, 23, 1-48.

Becker, D. F. P., Cunha, S., Goetz, M. N. B., Kieling-Rubio, M. A., \& Schmitt, J. L. (2013). Floristic of Ferns and Lycophytes in Forest Fragment of Watershed of Sinos River, Caraá, RS, Brazil. Pesquisas, Botânica, 64, 273-284. http://www.anchietano.unisinos.br/publicacoes/botanica/botanica64/17_becker\%20e\%20schmitt.pdf

Benzing, D. H. (1995). The Physical Mosaic and Plant Variety in Forest Canopies. Selbyana, 16, 159-168. http://www.jstor.org/stable/41759902

Bianchi, J. S., \& Kersten, R. A. (2014). Edge Effect on Vascular Epiphytes in a Subtropical Atlantic Forest. Acta Botanica Brasilica, 28, 120-126. http://dx.doi.org/10.1590/S0102-33062014000100012

Bianchi, J. S., Bento, C. M., \& Kersten, R. A. (2012).Vascular Epiphytes of an Araucaria-Atlantic Forest Ecotone at Pico do Marumbi State Park, Southern Brazil. Revista Estudos de Biologia, 34, 37-44. http://dx.doi.org/10.7213/estud.biol.6121

Blum, C. T., Roderjan, C. V., \& Galvão, F. (2011). Floristic Composition and Altitudinal Distribution of Vascular Epiphytes in the Ombrophilous Dense Forest of the Prata Mountain Range, Morretes, Paraná State, Brazil. Biota Neotropica, 11, 141-159. http://www.biotaneotropica.org.br/v11n4/pt/fullpaper?bn00811042011+pt http://dx.doi.org/10.1590/S1676-06032011000400015

Blume, M., Fleck, R., \& Schmitt, J. L. (2010). Richness and Composition of Ferns and Licophytes in a Hectare of Mixed Humid Forest in Rio Grande do Sul, Brazil. Revista Brasileira de Biociências, 8, 336-334. http://www.ufrgs.br/seerbio/ojs/index.php/rbb/article/view/1460

Bognola, I. A., Fasolo, P. J., Potter, R. O., Carvalho, A. P., \& Bhering, S. B. (2002). Survey and Recognition of Soils from the Central Region of State of Paraná. (Area 8). Rio de Janeiro: Embrapa Soils, 156p.

Borgo, M., \& Silva, S. M. (2003). Vascular Epiphytes in Fragment of Mixed Ombrophilous Forest, Curitiba, Paraná, Brazil. Brasilian Journal of Botany, 26, 391-401. http://dx.doi.org/10.1590/S0100-84042003000300012

Borgo, M., Silva, S. M., \& Petean, M. P. (2002). Vascular Epiphytes in a Fragment of Seasonal Semideciduous Forest, Municipality of Fenix, PR, Brazil. Acta Biológica Leopoldensia, 24, 121-130.

Bussad, W. O., Miazaki, E. S., \& Andrade, D. F. (1990). Introduction to Cluster Analysis. São Paulo: ABE, 105 p.

Cervi, A. C., \& Borgo, M. (2007). Vascular Epiphytes in the National Park of Iguaçu, Paraná (Brazil). Preliminary Survey. Fontqueria, 55, 415-422. http://bibdigital.rjb.csic.es/PDF/Fontqueria_55_51.pdf

Cervi, A. C., Acra, L. A., Rodrigues, L., Train, S., Ivanchechen, S. L., \& Moreira, A. L. O. R. (1987). Contribution to the Knowledge of the Pteridophytes of Araucaria Forest, Curitiba, Paraná, Brazil. Acta Biológica Paranaense, 16, 77-85. 
Christenhusz, M. J. M., Zhang, X. C., \& Schneider, H. (2011). A Linear Sequence of Extant Families and Genera of Lycophytes and Ferns. Phytotaxa, 19, 7-54. http://www.mapress.com/phytotaxa/content/2011/f/pt00019p054.pdf

Cislinski, J. (1996). The Genera Diplazium Sw. (Dryopteridaceae, Pteridophyta) in State of Paraná, Brazil. Acta Botanica Brasilica, 10, 59-77. http://dx.doi.org/10.1590/S0102-33061996000100006

Colli, A. M. T., Salino, A., Neto, E. J. R., Robinato, A. D., \& Estevam, E. C. (2007). Pteridophytes of State Reserve from Águas da Prata, Águas da Prata, SP. Revista Logos, 15, 11-18. http://www.feucriopardo.edu.br/logos/artigos/2007/artigo2 Aurea LOGOS 15 2007.pdf

Colli, A. M. T., Salino, A., Souza, S. A., Lucca, A. L. T., \& Silva, R. T. (2004). Pteridophytes of Vassununga State Park, Santa Rita do Passa Quatro (SP), Brazil, Glebas Capetinga East and Capetinga West. Revista do Instituto Florestal, 16, 25-30. http://www.iflorestal.sp.gov.br/publicacoes/revista_if/rev16-1pdf/25-30.pdf

Dettke, G. A., Orfrini, A. C., \& Milaneze-Gutierre, M. A. (2008) Floristic Composition and Distribution of Vascular Epiphytes in an Remaining Changed of Seasonal Semi Deciduous Forest of Paraná, Brasil. Rodriguésia, 59, 859-872. http://rodriguesia.jbrj.gov.br/FASCICULOS/rodrig59 4/014\%28071-07\%29.pdf

Dittrich, V. A. O., Kozera, C., \& Silva, S. M. (1999). Floristic Survey of Vascular Epiphytes from Barigüi Park, Curitiba, Paraná, Brazil. Iheringia, Série Botânica, 52, 11-21.

Dittrich, V. A. O., Waechter, J. L., \& Salino, A. (2005). Species Richness of Pteridophytes in a Montane Atlantic Rain Forest Plot of Southern Brazil. Acta Botanica Brasilica, 19, 519-525. http://dx.doi.org/10.1590/S0102-33062005000300013

Dombrowski, L. T. D. (1972). Collection of Pteridophytes from Paraná in Defense Institute of Natural Heritage (IDPN). Araucariana, 2, 1-30.

Embrapa (2006). Brazilian Systemof Soil Classification. Brasília: Embrapa Production Information. Rio de Janeiro: Embrapa Soils, 412 p.

Gaiotto, D. F., \& Acra, L. A. (2005). Qualitative Survey of Epiphytes from Gralha Azul Farm-Rio Grande Farm, Paraná. Revista Estudos de Biologia, 27, 25-32. http://www2.pucpr.br/reol/index.php/BS?dd1=144\&dd99=view

Geraldino, H. C. L., Caxambú, M. G., \& Souza, D. C. (2010). Floristic Composition and Community Structure of Vascular Epiphytes in Ecotone Area of Campo Mourão, PR, Brazil. Acta Botanica Brasilica, 24, 469-482. http://dx.doi.org/10.1590/S0102-33062010000200018

Goetz, M. N. B., Fraga, L. L., \& Schmitt, J. L. (2012). Floristic and Ecological Aspects of Ferns and Lycophytes in Urban Park of Rio Grande do Sul, Brazil. Pesquisas: Botânica, 63, 165-176.

http://www.anchietano.unisinos.br/publicacoes/botanica/botanica63/07.pdf

Gonzatti, F., Valduga, E., Wasum, R. A., \& Scur, L. (2014). Floristic and Ecological Aspects of Ferns and Lycophytes in Remaining of Seasonal Deciduous Forest of Gaúcha Ridge, Rio Grande do Sul. Revista Brasileira de Biociências, 12, 9097. http://www.ufrgs.br/seerbio/ojs/index.php/rbb/article/viewFile/2759/1242

Hammer, O., Harper, D. A. T., \& Ryan, P. D. (2001). PAST: Paleontological Statistics Software Package for Education and Data Analysis. Palaeontologia Electronica, 4, 9 p.

Ibge (1997). Municipal Division of the Brazilian Institute of Statistics Geography. http://www.cidades.ibge.gov.br/xtras/perfil.php?lang=\&codmun=410430\&search=parana|campo-mourao

Johnson, R. A., \& Wichern, D. W. (2002). Applied Multivariate Statistical Analysis (5 ed.). New York: Prentice Hall, 512 p.

Kersten, R. A., \& Kuniyoshi, Y. S. (2009). Conservation of Forests in Basin of High Iguaçú, Praná—Avaliation of Vascular Epiphytes Comunity in Different Seral Stages. Revista Floresta, 39, 51-66.

http://ojs.c3sl.ufpr.br/ojs2/index.php/floresta/article/view/13726

Kersten, R. A., \& Silva, S. M. (2001). Floristic Composition and Structure of Vascular Epiphytic Component in Forest of Coastal Plain in Ilha do Mel, Paraná, Brazil. Brazilian Journal of Botany, 24, 213-226.

http://dx.doi.org/10.1590/S0100-84042001000200012

Kersten, R. A., \& Silva, S. M. (2002). Floristic and Structure of Vascular Epiphytic Component Alluvial Mixed Ombrophilous Forest of Birigui River, Paraná, Brazil. Brazilian Journal of Botany, 5, 259-267. http://dx.doi.org/10.1590/S0100-84042002000300002

Kozera, C., Rodrigues, R. R., \& Dittrich, V. A. O. (2009). Floristic Composition of Sub-Forest of a Montane Dense Ombrophilous Forest, Morretes, PR, Brazil. Floresta, 39, 323-334. http://ojs.c3sl.ufpr.br/ojs2/index.php/floresta/article/view/14559

Lehn, C. R., Leuchtenberger, C., \& Hansen, M. A. F. (2009). Pteridophytes in Two Remaining of Seasonal Decidual Forest in Taquari River Valley, State of Rio Grande do Sul, Brazil. Iheringia, Série Botânica, 64, 23-31.

http://www.fzb.rs.gov.br/upload/20140328113054ih64_1_p023_031.pdf 
Maack, R. (1950). Phytogeographical Map of Paraná State. Curitiba, Agriculture, Industry and Trade Department, 1 Map, Scale 1:750.000.

Maack, R. (1968). Physical Geography of Paraná State. Curitiba: Development Bank of Paraná, Federal University of Paraná and Institute of Biology and Technology Research, 350 p.

Magurran, A. E. (2004). Measuring Biological Diversity. Malden: Blackwell Science, 256 p.

Mallmann, I. T., Rocha, L. D., \& Schmitt, J. L. (2014). Richness and Floristic Composition of Ferns Community in Riparian Forest of the River “Cadeia” in Rio Grande do Sul State, Brazil. Ciência Florestal, 24, 97-109. www.ufrgs.br/seerbio/ojs/index.php/rbb/article/download/2070/1186

Michelon, C., \& Labiak, P. H. (2013). Ferns and Lycophytes of Guartelá State Park, PR, Brazil. Hoehnea, 40, 191-204. http://dx.doi.org/10.1590/S2236-89062013000200001

Missouri Botanical Garden (2014). W3tropicos: Nomenclatural Database. http://www.tropicos.org/

Moran, R. C. (1995). The Importance of Mountains to Pteridophytes, with Emphasis on Neotropical Montane Forests. In S. P., Churchill (Ed.), Biodiversity and Conservation of Neotropical Montane Forest (pp. 359-363). New York: The New York Botanical Garden.

Moran, R. C. (2004). Los géneros neotropicales de helechos y licófitos: Uma guia para estudiantes. New York: The New York Botanical Garden, 278 p.

Moran, R. C. (2008). Diversity, Biogeography, and Floristics. In T. A. Ranker, \& C. H. Haufler (Eds.), Biology and Evolution of Ferns and Lycophytes (pp. 201-221). New York: Cambridge University Press. http://dx.doi.org/10.1017/CBO9780511541827.015

Müller-Dombois, D., \& Ellenberg, H. (1974). Aims and Methods in Vegetation Ecology. New York: John Wiley and Sons.

Nóbrega, G. A., \& Prado, J. (2008). Pteridophytes os Native Vegetation of Municipal Botanical Garden of Bauru, São Paulo, Brazil. Hoehnea, 35, 7-55. http://dx.doi.org/10.1590/S2236-89062008000100001

Page, C. (2002). Ecological Strategies in Fern Evolution: A Neopteridological Overview. Review of Palaeobotany and Palynology, 119, 1-33. http://dx.doi.org/10.1016/S0034-6667(01)00127-0

Parker, G. G. (1995). Structure and Microclimate of Forest Canopies. In: M. D. Lowman, \& N. M. Nadkarni (Eds.), Forest Canopies (pp. 73-106). San Diego: Academic Press.

Páusas, J. G., \& Sáez, L. (2000). Pteridophyte Richness in the NE Iberian Peninsula: Biogeographic Patterns. Plant Ecology, 148, 195-205. http://dx.doi.org/10.1023/A:1009899615852

Pichi-Sermolli, R. E. G. (1996). Authors of Scientific Names in Pteridophyta. Royal Botanical Gardens, Kew, 78 p.

Prado, J. (1998). Pteridophytes of São Paulo State. In C. E. M. Bicudo, \& G. J. Shepherd (Eds.), Biodiversity of São Paulo State. Synthesis of Knowledge at the End Century XX. Vol. 2. Macroscopic Fungi \& Plants (pp. 49-61). São Paulo: Foundation for Research Support of São Paulo State (Fapesp).

Prado, J., \& Sylvestre, L. S. (2010). Introduction: The Ferns and Lycophytes of Brazil. In: R. C., Forzza et al., (org.) Research Institute Botanical Garden of Rio de Janeiro: Catalog of plants and fungi of Brazil (online). Research Institute Botanical Garden of Rio de Janeiro (pp. 69-74). Rio de Janeiro: Andrea Jakobsson Studio.

Prado, J., \& Sylvestre, L. S. (2014). Ferns and Licophytes. Species List of Flora of Brazil. http://reflora.jbrj.gov.br/jabot/listaBrasil/ConsultaPublicaUC/ConsultaPublicaUC.do

Pryer, K. M., Schneider, H., Smith, A. R., Cranfill, R., Wolf, P. G., Hunt, J. S., \& Sipes, S. D. (2001). Horsetails and Ferns Are a Monophyletic Group and the Closest Livings Relatives to Seed Plants. Nature, 409, 618-622. http://dx.doi.org/10.1038/35054555

Pryer, K. M., Schuettpelz, E., Wolf, P. G., Schneider, H., Smith, A. R., \& Cranfill, R. (2004). Phylogeny and Evolution of Ferns (Monilophytes) with a Focus on the Early Leptosporangiate Divergences. American Journal of Botany, 91, 15821598. http://dx.doi.org/10.3732/ajb.91.10.1582

Roderjan, C. V., Galvão, F., Kuniyoshi, Y. S., \& Hatschback, G. (2002). The Phytogeographic Units of Paraná State. Ciência e Ambiente, 24, 75-92.

Schmitt, J. L., \& Goetz, M. N. B. (2010). Species Richness of Fern and Lycophytes in an Urban Park in the Sinos River Basin, Southern Brazil. Brazilian Journal of Biology, 70, 1161-1167. http://dx.doi.org/10.1590/S1519-69842010000600005

Schmitt, J. L., Fleck, R., Burmeister, E. L., \& Rubio, M. A. K. (2006). Diversity and Biological Forms of Pteridophytes of National Forest of Cinnamon, Rio Grande do Sul: Contributions to the Management Plan. Pesquisas, Botânica, 57, 275288. www.anchietano.unisinos.br/publicacoes/botanica/botanica57/artigo13.pdf

Schwartsburd, P. B., \& Labiak, P. H. (2007). Pteridophytes of Vila Velha State Park. Ponta Grossa, Paraná, Brazil. Hoehnea, 34, 159-209. http://dx.doi.org/10.1590/S2236-89062007000200005 
Smith, A. R., Pryer, K. M., Schuettpelz, E., Korall, P., Schneider, H., \& Wolf, P. G. (2006). A Classification for Extant Ferns. Taxon, 55, 705-731. https://pryerlab.biology.duke.edu/uploads/media_items/smith-et-al-taxon-2006.original.pdf http://dx.doi.org/10.2307/25065646

Smith, A. R., Pryer, K. M., Schuettpelz, E., Korall, P., Schneider, H., \& Wolf, P. G. (2008). Fern Classification. In T. A. Ranker, \& C. H. Haufler (Eds.), The Biology and Evolution of Ferns and Lycophytes (pp. 417-467). Cambridge: Cambridge University Press.

Species List of Brazilian Flora (2014). Botanical Garden of Rio de Janeiro. http://reflora.jbrj.gov.br/jabot/PrincipalUC/PrincipalUC.do

Steffens, C., \& Windisch, P. G. (2007). Diversity and Life Forms of Pteridophytes of Harmonia Hill in Teutônia-RS, Brazil. Pesquisas, Botânica, 58, 375-382. http://www.anchietano.unisinos.br/publicacoes/botanica/botanica58/artigo14.pdf

Tryon, R. M. (1986). Biogeography of Species, with Special Reference to Ferns. Botanica Reviews, 52, 117-156. http://dx.doi.org/10.1007/BF02860999

Windisch, P. G. (1990). Pteridophytes of North-Western Region of São Paulo State. Guide to Excursions. São Paulo: UNESP.

Zotz, G., \& Hietz, P. (2001). The Physiological Ecology of Vascular Epiphytes: Current Knowledge, Open Questions. Journal of Experimental Botany, 52, 2067-2078. 
Scientific Research Publishing (SCIRP) is one of the largest Open Access journal publishers. It is currently publishing more than 200 open access, online, peer-reviewed journals covering a wide range of academic disciplines. SCIRP serves the worldwide academic communities and contributes to the progress and application of science with its publication.

Other selected journals from SCIRP are listed as below. Submit your manuscript to us via either submit@scirp.org or Online Submission Portal.
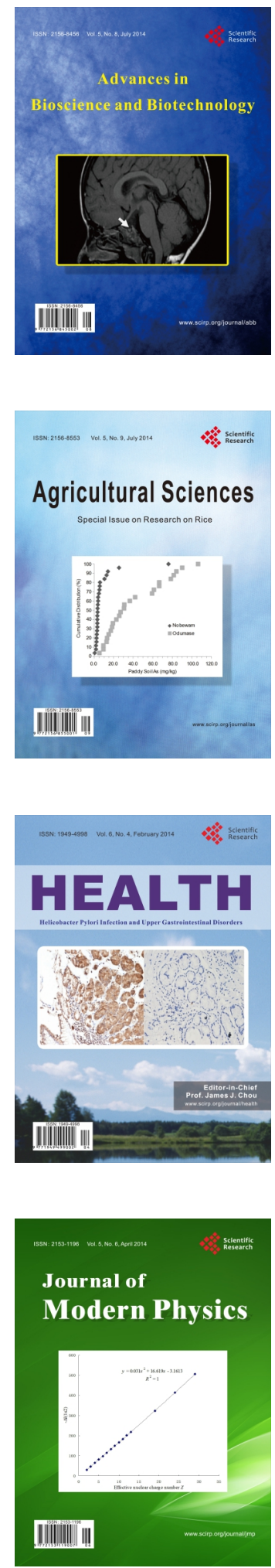
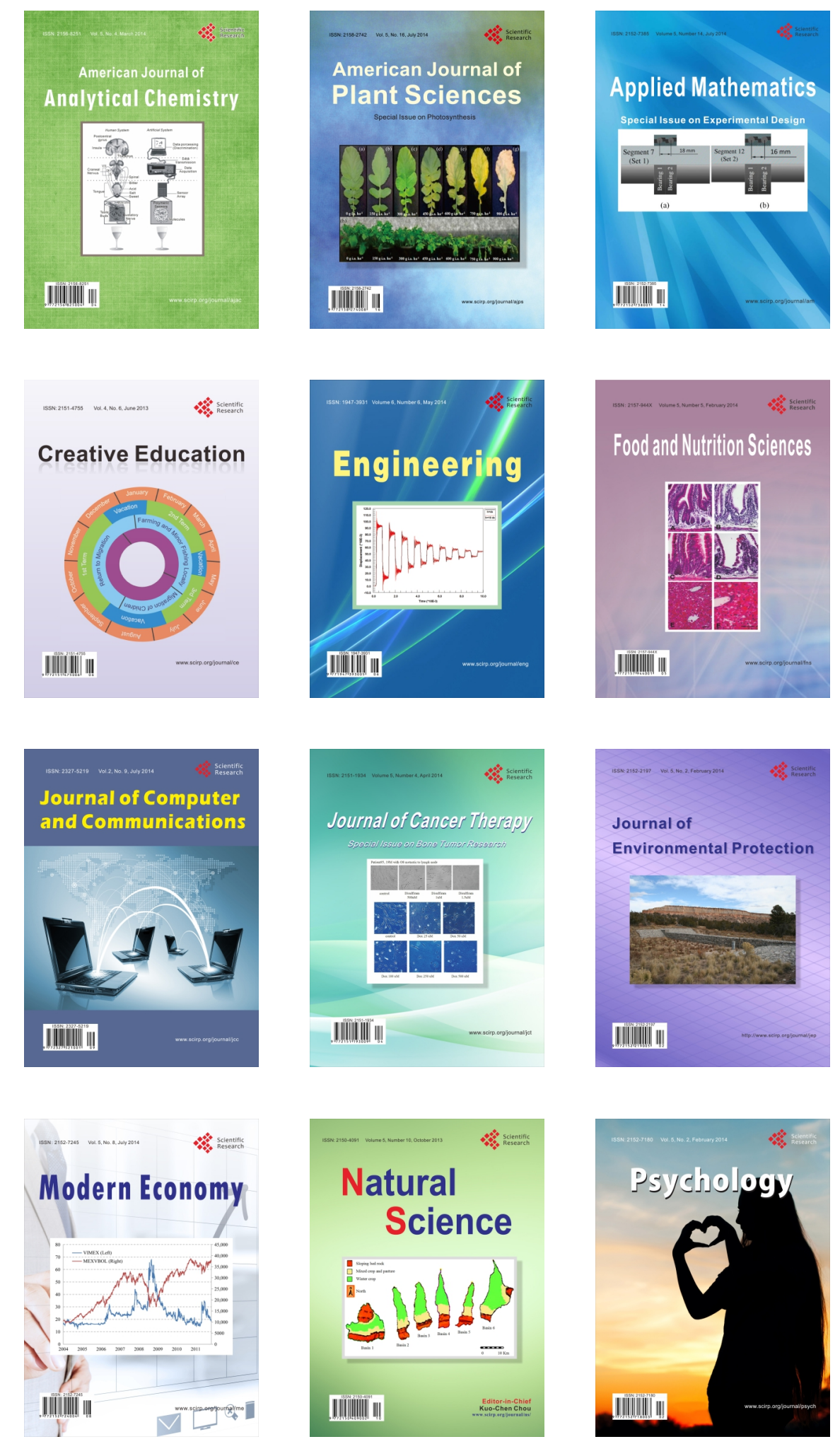